\title{
Effects of Membrane Trafficking on Signaling by Receptor Tyrosine Kinases
}

\author{
Marta Miaczynska \\ International Institute of Molecular and Cell Biology, Laboratory of Cell Biology, 02-109 Warsaw, Poland \\ Correspondence: miaczynska@iimcb.gov.pl
}

The intracellular trafficking machinery contributes to the spatial and temporal control of signaling by receptor tyrosine kinases (RTKs). The primary role in this process is played by endocytic trafficking, which regulates the localization of RTKs and their downstream effectors, as well as the duration and the extent of their activity. The key regulatory points along the endocytic pathway are internalization of RTKs from the plasma membrane, their sorting to degradation or recycling, and their residence in various endosomal compartments. Here I will review factors and mechanisms that modulate RTK signaling by (1) affecting receptor internalization, (2) regulating the balance between degradation and recycling of RTK, and (3) compartmentalization of signals in endosomes and other organelles. Cumulatively, these mechanisms illustrate a multilayered control of RTK signaling exerted by the trafficking machinery.

\begin{abstract}
$A^{t}$ the cellular level, receptor tyrosine kinases A(RTKs) need to be properly localized to function as signal-receiving and signal-transmitting devices (Lemmon and Schlessinger 2010). To receive signals (i.e., to bind extracellular ligands), RTKs have to be exposed at the surface of the plasma membrane. To transmit signals after ligand binding by RTKs, appropriate signaling components have to be available within intracellular compartments: in the cytoplasm, in association with membrane-bound organelles and in the cell nucleus. Importantly, the intracellular distribution of RTKs and their associated partners is not static but undergoes dynamic changes in different phases of signaling, as reflected for example by endocytic internalization of activated RTKs (Scita and Di Fiore 2010). Therefore, to function properly, the
\end{abstract}

whole RTK signaling machinery within the cell has to be organized and tightly controlled both in space and in time. This organization and control are ensured by intracellular trafficking machineries, mainly by membrane transport systems such as endocytosis and secretion but also by other distribution systems (e.g., responsible for nucleocytoplasmic shuttling of proteins).

Recent years have brought increasing evidence that intracellular membrane trafficking, in particular endocytic internalization, degradation, and recycling, can profoundly affect the signaling properties of RTKs (Mukherjee et al. 2006; Abella and Park 2009; Lemmon and Schlessinger 2010; Scita and Di Fiore 2010; Grecco et al. 2011; Sigismund et al. 2012). The changes in the amounts of RTKs at the cell surface can alter the cellular responses when ligands

Editors: Joseph Schlessinger and Mark A. Lemmon

Additional Perspectives on Signaling by Receptor Tyrosine Kinases available at www.cshperspectives.org

Copyright (C) 2013 Cold Spring Harbor Laboratory Press; all rights reserved; doi: 10.1101/cshperspect.a009035

Cite this article as Cold Spring Harb Perspect Biol 2013;5:a009035 
M. Miaczynska

are abundant (Grecco et al. 2011). In turn, the presence of a given RTK at the plasma membrane is determined by the rates of three trafficking processes: delivery of newly synthesized molecules by the secretory pathway, their internalization (occurring for both ligand-bound and ligand-free molecules), and endocytic recycling. Although the molecular details concerning the regulation of RTK delivery to the plasma membrane are not well known, numerous studies document various mechanisms by which internalization and recycling of RTKs can be modulated, thus affecting the signaling outputs (Le Roy and Wrana 2005). In addition to the regulation of RTKs at the cell surface, trafficking processes control the intracellular fate of endocytosed RTKs. Following internalization, RTKs can be either targeted for lysosomal degradation, or recycled back to the plasma membrane (Mukherjee et al. 2006; Abella and Park 2009; Scita and Di Fiore 2010). The first route results in the termination of signaling, whereas the second allows for sustained signaling if the ligand is available. Usually degradation and recycling of a given RTK can occur simultaneously but the balance between them is crucial to determine the net signaling output. Again, the molecular mechanisms that can shift the fate of internalized RTKs between degradation and recycling, thus changing RTK signaling, have begun to emerge in recent years (Polo and Di Fiore 2006; von Zastrow and Sorkin 2007; Sorkin and von Zastrow 2009; Sigismund et al. 2012). Finally, in contrast to an early view that only RTKs present at the plasma membrane are signaling competent, it is now accepted that in many cases activated RTKs can emit signals also after internalization into intracellular compartments (Miaczynska et al. 2004b; Miaczynska and Bar-Sagi 2010; Platta and Stenmark 2011). In some cell types (e.g., in neurons), such "signaling endosomes" are crucial for signal propagation within the cell and for the final cellular response. Moreover, endosomes can serve as platforms for amplification and compartmentalization of signals emitted by RTKs (Sadowski et al. 2009; Platta and Stenmark 2011).

In this article, I will review factors and mechanisms that modulate RTK signaling by (1) af- fecting receptor internalization, (2) regulating the balance between degradation and recycling of RTK, and (3) compartmentalization of signals in endosomes and other organelles. As the membrane trafficking system of a cell is highly interconnected and can be considered a global dynamic continuum, it is important to note that often one primary alteration at a given stage of RTK trafficking may affect other transport steps or compartments, thus causing generalized changes in the intracellular routing and signaling of RTKs.

\section{MODULATION OF RTK SIGNALING BY CHANGES IN ENDOCYTIC INTERNALIZATION}

RTKs can undergo constitutive or ligand-induced internalization from the plasma membrane, the latter being responsible for downregulation of receptors from the cell surface following activation. Recent progress in the field of endocytosis revealed that internalization can occur via multiple structures formed from the plasma membrane. Among them are clathrin-coated vesicles (CCVs), caveolae, macropinosomes, clathrin- and dynamin-independent carriers (CLICs), and other less-characterized endocytic structures (Conner and Schmid 2003; Mayor and Pagano 2007; Howes et al. 2010; McMahon and Boucrot 2011). These different entry routes are often classified based on the involvement of a large GTPase dynamin as dynamin dependent (CCVs, caveolae) or dynamin independent (macropinocytosis, the CLIC pathway). As GTPase activity of dynamin can be inhibited by mutations or pharmacologically, these tools are often used to determine the impact of dynamin-mediated internalization on RTK signaling.

Historically, the use of a GTPase-deficient dynamin K44A mutant underlies one of the first reports that impaired endocytosis of epidermal growth factor receptor (EGFR) may affect a number of its downstream signaling molecules, with some being hyperactivated (phospholipase-C $\gamma$ and adaptor protein SHC) and others less active ( phosphatidylinositol 3-kinase $[\mathrm{PI} 3 \mathrm{~K}]$ and mitogen-activated protein kinases 
[MAPKs]) (Vieira et al. 1996). However, these early observations have been recently challenged by the study in which conditional depletion of dynamin in mouse fibroblasts inhibited EGFR endocytosis but did not affect the activation of MAPK or Akt on EGF stimulation (Sousa et al. 2012). Therefore, these data argued that the MAPK/Akt responses are elicited by EGFR at the plasma membrane and not by EGFR internalized into endosomes. Similarly, another recent study reported that the global transcriptional response to EGF is initiated primarily by the ligand-bound receptors at the plasma membrane (Brankatschk et al. 2012). These controversies indicate that signaling of activated RTKs after internalization is not an absolute requirement for their biological function. However, it cannot be excluded that in some cell types or under certain conditions signaling from RTKs localized in endosomes may contribute to the modulation of cellular responses.

An important recent concept is the notion that some factors, such as ligand concentration, can influence the preferred internalization route of a receptor, what determines its further sorting either toward degradation or recycling. Moreover, internalization of RTKs can be modulated by stress factors or stimuli other than their cognate ligands, affecting the signaling outcome. In addition, it appears that endocytic internalization and recycling of RTKs can occur in specialized plasma membrane microdomains, contributing to the determination of cell polarity. These aspects are discussed in detail below.

Different Entry Routes and Intracellular Fates of RTKs Dependent on Ligand Concentration

It appears that multiple cargo uptake mechanisms operate simultaneously in most cells and different entry routes can, to some extent, compensate for each other if one is blocked (Pelkmans et al. 2005). Different RTKs were shown to use various pathways, both dynamin dependent and independent, but the molecular basis for their selective use is still far from being understood. Ligand concentration is a postulated regulatory factor proposed for EGFR, which is the best-characterized RTK with respect to endo- cytic trafficking (Fig. 1A). It was reported that at low ligand concentrations $(\sim 1 \mathrm{ng} / \mathrm{mL}$ EGF) EGFR is primarily internalized via clathrinmediated endocytosis (Jiang and Sorkin 2003; Sigismund et al. 2005), whereas at higher concentrations $(>20 \mathrm{ng} / \mathrm{mL})$ EGFR enters cells both via clathrin-dependent and -independent routes (Sigismund et al. 2005). Both levels of ligand abundance are physiological, as the range of EGF concentration in different body fluids is rather broad $(1-100 \mathrm{ng} / \mathrm{mL})$. It was further proposed that clathrin-mediated internalization leads to increased recycling of EGFR and is required for the induction of DNA synthesis in a mitogenic response. In turn, lysosomal degradation is the main outcome of clathrin-independent endocytosis of EGFR (Fig. 1A) (Sigismund et al. 2008). In this way, low ligand concentrations would favor sustained and prolonged signaling via the continuous redelivery of EGFR to the plasma membrane, whereas high amounts of ligand would reduce the levels of the receptor at the cell surface, thus preventing cell overstimulation and eventually terminating signaling. It is, however, important to note that such dependence may not be universal but rather cell-type dependent, as others reported less degradation and higher recycling rates of EGFR on stimulation with high EGF concentrations (French et al. 1994) or no observable clathrin-independent endocytosis under these conditions (Kazazic et al. 2006).

With respect to other RTKs, low $(1 \mathrm{ng} / \mathrm{mL})$ or high $(>5 \mathrm{ng} / \mathrm{mL})$ concentrations of plateletderived growth factor (PDGF) cause preferential activation of different signaling effectors and eventually result in PDGFR signaling toward cell migration or toward proliferation, respectively (De Donatis et al. 2008). By analogy to EGF, these differences in signaling were proposed to result from the selective use of distinct internalization pathways by PDGFR stimulated with various amounts of the ligand. Recently, PDGF was shown to undergo dynamin-dependent and -independent internalization but the activity of dynamin and high ligand concentration were specifically required for the mitogenic signaling via signal transducer and activator of transcription 3 (Stat3) and Myc (Sadowski 
M. Miaczynska

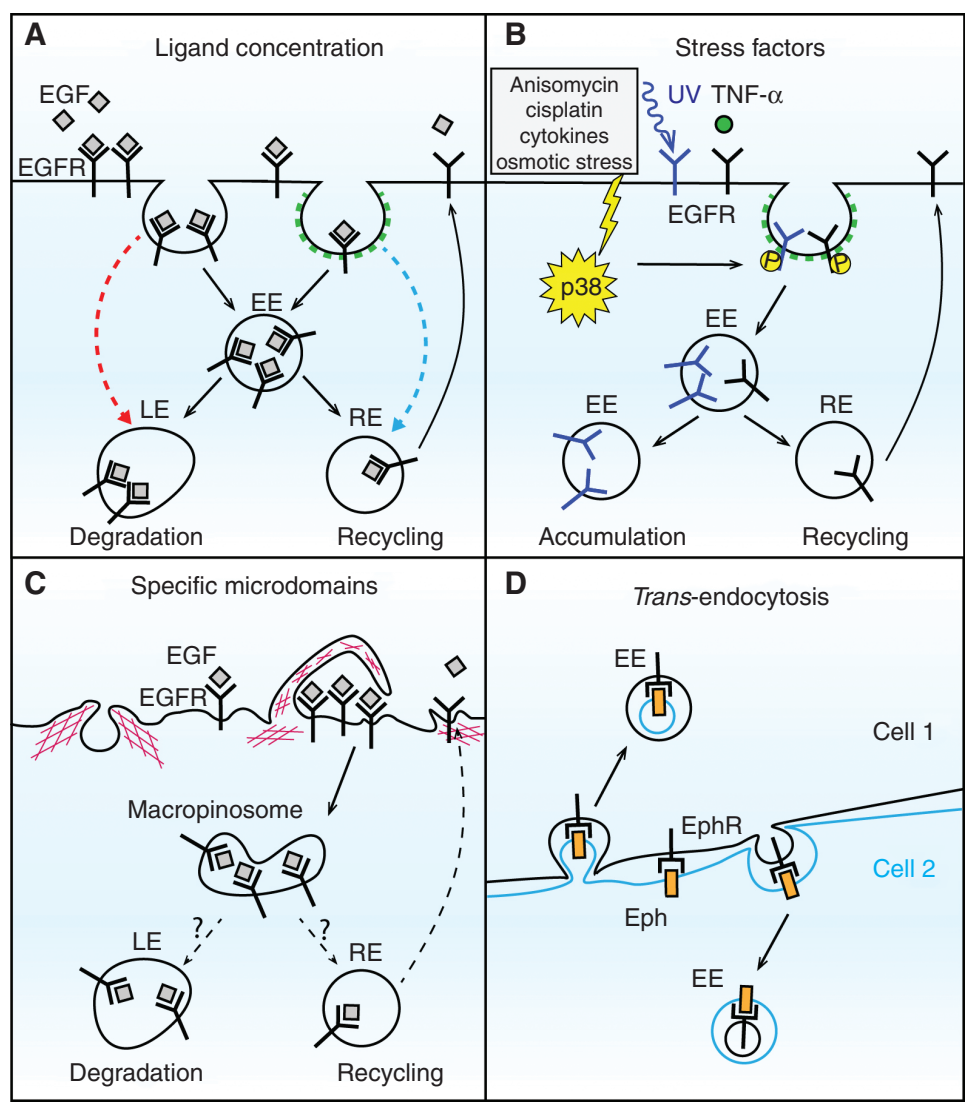

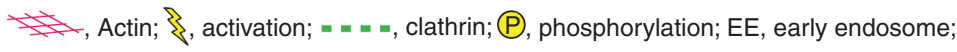

LE, late endosome; RE, recycling endosome.

Figure 1. Different factors and mechanisms affecting RTK internalization from the plasma membrane. $(A)$ Ligand concentration influences clathrin-dependent or -independent internalization of EGFR and its further trafficking toward degradation (high EGF concentration, red arrow) or recycling (low concentration, blue arrow). (B) Stress factors activating p38 MAPK stimulate ligand-independent internalization of EGFR. UV irradiation induces prolonged accumulation of EGFR in endosomes (marked in blue), whereas TNF- $\alpha$ increases receptor recycling (marked in black). (C) Dorsal ruffles represent plasma membrane microdomains for preferential localized internalization of EGFR into macropinosomes. Its further trafficking within the cell is not entirely clear. $(D)$ Trans-endocytosis enables internalization of ephrin-Eph receptor complexes (Eph-EphR) into two neighboring cells in forward and reverse directions.

et al. 2013). Moreover, macropinocytosis of PDGFR- $\beta$ (induced, for example, by an oncogenic mutant $\mathrm{H}$-RasG12V) increased its signaling activity and anchorage-independent cell proliferation (Schmees et al. 2012).

The general concept of different signaling outcomes being dependent on a particular internalization route is supported by the data from the receptor systems other than RTKs. A serine/threonine kinase receptor for transform- ing growth factor- $\beta$ (TGF- $\beta$ R) can be internalized via clathrin vesicles or caveolae. The former route activates downstream signaling effectors but the latter one leads to the rapid degradation of the receptor, thus terminating the signaling (Di Guglielmo et al. 2003). The opposite relationship was reported for the Wnt coreceptor LRP6. Wnt3a-stimulated uptake of LRP6 occurs via caveolae, which activates signaling via stabilization of $\beta$-catenin. In contrast, Wnt antago- 
nist Dickkopf induces LRP6 internalization via the clathrin pathway, which prevents $\beta$-catenin signaling (Yamamoto et al. 2008). Cumulatively, these data argue that different internalization routes can be associated with the particular signaling outcomes but the exact functional relationships may vary for different ligand-receptor pairs and in different cell types.

Modulation of RTK Internalization by Stress Factors or Stimuli Other than the Cognate Ligands

As for any plasma membrane proteins, RTKs undergo constitutive turnover, including internalization, recycling, and degradation at basal cell type-specific rates. Ligand binding and receptor activation can significantly stimulate internalization of ligand-receptor complexes, as shown early on for insulin receptor, EGFR, PDGFR, hepatocyte growth factor (HGF) receptor Met, and others (Schlessinger et al. 1978; Heldin et al. 1982; Wiley et al. 1991; Naka et al. 1993). The molecular mechanism by which a ligand can regulate the rate of its own internalization in complex with a cognate RTK was proposed for EGFR. In this case EGF binding induces Ras-mediated activation of Rin1. This nucleotide exchange factor (GEF) activates in turn the small GTPase Rab5, which is a ratelimiting component for endocytic internalization (Tall et al. 2001). However, internalization rates of RTKs can be modulated also by factors other than the binding of cognate ligands, such as various types of stress, other signaling pathways, hypoxia, or molecules regulating cell adhesion (discussed below). These mechanisms provide an explanation for the often-reported cross talk between different signaling pathways. In the cases of such transmodulation, a heterologous stimulus can alter the levels of an RTK at the plasma membrane, thus regulating the overall cell responsiveness to a given ligand and a final signaling output of the receptor.

\section{Stress Factors and Signaling Kinases}

Several stress factors activating p38 MAPK, such as inflammatory cytokines (e.g., tumor necrosis factor $\alpha$ [TNF- $\alpha]$ ), UV irradiation, osmotic stress, or certain drugs (anisomycin, cisplatin), can stimulate internalization of ligandfree EGFR (Fig. 1B) (Vergarajauregui et al. 2006; Winograd-Katz and Levitzki 2006; Zwang and Yarden 2006; Singhirunnusorn et al. 2007). p38 MAPK stimulates clathrin-mediated internalization of EGFR by phosphorylating both EGFR and the components of the endocytic machinery, such as Rab GDP dissociation inhibitor (GDI) and Rab5 effectors EEA1 and Rabenosyn5 (Cavalli et al. 2001; Mace et al. 2005; Zwang and Yarden 2006). Interestingly, the fate of internalized EGFR can differ with various types of stimuli. For example, TNF- $\alpha$ treatment results in increased recycling of EGFR to the plasma membrane, whereas UV irradiation causes persistent intracellular accumulation of EGFR in endosomes, thus making the cells irresponsive to EGFR ligands (Fig. 1B) (Zwang and Yarden 2006). In addition to p38 MAPK-regulated trafficking, internalization of ligand-free EGFR can be induced on activation of protein kinase $C$ (PKC) or inhibition of protein kinase A (PKA) (Beguinot et al. 1985; Lin et al. 1986; Salazar and Gonzalez 2002; Norambuena et al. 2010). In the case of VEGF, the activity of atypical PKC (aPKC) was shown to control vascular endothelial growth factor receptor (VEGFR) internalization and trafficking, thus regulating angiogenesis (Nakayama et al. 2013). Low activity of aPKC in endothelial sprouts of growing vessels contributes to high internalization and turnover of VEGFR, concomitant with increased signaling. In turn, high aPKC activity in mature vessels suppresses VEGFR endocytosis and signaling.

\section{Hypoxia}

Another mechanism modulating the internalization rates of RTKs is hypoxia. Under hypoxic conditions or on loss of a negative regulator of hypoxia, von Hippel-Lindau (VHL) protein, EGFR endocytosis is slowed down and the receptor half-life increased, leading to enhanced EGFR signaling (Wang et al. 2009). This is owing to the inhibition of Rab5-dependent fusion of early endosomes, resulting from the hypoxia-induced transcriptional down-regulation of 
M. Miaczynska

Rab5 effector Rabaptin-5. Moreover, the levels of Vps4B ATPase that regulate endosomal trafficking are down-regulated on hypoxia, which leads to the accumulation of EGFR and its increased signaling (Lin et al. 2012). Similarly, loss of VHL impairs internalization of fibroblast growth factor receptor 1 (FGFR1), causing its accumulation on the cell surface and enhanced signaling leading to increased cell motility on FGF stimulation (Hsu et al. 2006; Champion et al. 2008).

\section{Regulators of Cell Adhesion}

Molecules regulating cell adhesion or components of the extracellular matrix can affect the internalization rates of RTKs, both ligandbound and ligand-free. Several types of cadherins were shown to interact with various RTKs, modulating their internalization and activation in complex, sometimes opposite, ways $(\mathrm{Mu}-$ kherjee et al. 2006; Orian-Rousseau and Ponta 2008; Delva and Kowalczyk 2009). For example, $\mathrm{N}$-cadherin was reported to reduce internalization of the FGF2-FGFR1 complex, thereby causing sustained MAPK activation, increased transcription of MMP-9, and enhanced cell invasion (Suyama et al. 2002). Mutant E-cadherin associated with gastric cancer inhibited ligandstimulated internalization of EGFR and enhanced its activation (Bremm et al. 2008). In contrast, wild-type E-cadherin was shown to block internalization of FGFR1 after stimulation with FGF1 or FGF2 but in this case MAPK signaling and FGFR1 translocation to the nucleus were inhibited, arguing that under these experimental conditions receptor endocytosis was required for sustained downstream signaling (Bryant et al. 2005). Similarly, as vascular endothelial growth factor receptor 2 (VEGFR2) was proposed to signal mainly from the intracellular compartments, inhibition of its internalization by VE-cadherin was therefore inhibitory for VEGFR2-induced cell proliferation (Lampugnani et al. 2006). Importantly, in many cases cadherins can be cointernalized along with the RTKs. This may provide a mechanism for the coordination of changes in cell adhesion with RTK-specific signaling. Finally, certain extracel- lular molecules, particularly containing leucinerich repeats such as decorin and LRIG1, were reported to affect internalization of several RTKs, such as ErbB receptors, Met, or insulinlike growth factor receptor (IGF-IR), affecting their signaling outputs (Gur et al. 2004; Laederich et al. 2004; Zhu et al. 2005; Shattuck et al. 2007; Goldoni and Iozzo 2008; Goldoni et al. 2009). Similarly, heparan sulfate proteoglycans, such as syndecans, can modulate endocytosis and signaling of RTKs, as shown recently for syndecan 4 , which promotes macropinocytosis of FGFR1 and regulates its downstream signaling via MAPK (Elfenbein et al. 2012).

\section{Spatial Regulation of RTK Internalization}

Locally restricted internalization of RTKs emerges as an important although still poorly investigated aspect regulating signaling. It is now well accepted that the plasma membrane consists of various microdomains differing in composition and function, both in cells permanently polarized such as neurons or epithelia but also in cells, reversibly establishing short-term polarity like migrating fibroblasts (Mellman and Nelson 2008; Winckler and Mellman 2010; Schiefermeier et al. 2011). Therefore, it is reasonable to expect that the rates of endocytic uptake and the types of internalized cargo may differ in various microdomains of the plasma membrane (Disanza et al. 2009). For example, polarized endocytosis of FGFR2 on ligand stimulation occurs in the leading edge of migrating keratinocytes (Belleudi et al. 2011). Moreover, growth factor ligands of RTKs such as EGF, PDGF, or HGF change cell morphology by inducing plasma membrane ruffling in the form of peripheral (planar) or dorsal (circular) ruffles. These actin-rich protrusions can be used for macropinocytosis when ruffles fuse with each other enclosing large volumes of extracellular fluid, thus forming macropinosomes (Kerr and Teasdale 2009). Circular ruffles, which form transiently after growth factor stimulation at the dorsal side of a cell, were proposed to act as microdomains for preferential RTK endocytosis, as $50 \%$ of ligand-bound EGFR was shown to be internalized via these structures (Fig. 1C) 
(Orth et al. 2006). In parallel, dorsal ruffles function also as sites for preferential RTK signaling required for biological responses, as evidenced for Met, which needs to signal from the dorsal ruffles to induce epithelial migration and morphogenesis (Abella et al. 2010a,b).

A special case of regulated internalization is represented by Eph receptors, which interact with membrane-bound ephrin ligands and signal in a cell-contact-dependent manner to control adhesion, migration, and various aspects of tissue morphogenesis (Pasquale 2008). Ephephrin complexes, in which ligand and receptor are embedded in the plasma membrane of two neighboring cells, are internalized locally by trans-endocytosis (Fig. 1D). In this poorly characterized process a piece of the plasma membrane of one cell is taken up into the other cell. It is postulated that trans-endocytosis (which can occur in forward and reverse directions) has profound consequences for the signaling outcomes depending on the cell type and other molecules cointernalized together with Ephephrin complexes (reviewed in Pitulescu and Adams 2010).

A key role of endocytic internalization and trafficking in spatial restriction of RTK signaling in vivo was shown in studies of collective migration of border cells during oogenesis in Drosophila (Jeffers et al. 1997; Jekely et al. 2005; Assaker et al. 2010). In this process, two RTKs, EGFR and PVR (a fly homolog of PDGFR and VEGFR), are localized specifically to the leading edge of the moving cells, maintained there by spatially restricted cycles of internalization and recycling. Mutations in several components of the endocytic machinery result in severe migration defects caused by delocalized activity of these RTKs, indicating a crucial role of membrane trafficking in establishing cell polarity.

\section{MECHANISMS REGULATING THE BALANCE BETWEEN DEGRADATION AND RECYCLING OF RTKS AND THEIR IMPACT ON SIGNALING}

As already mentioned, the balance between degradation and recycling for a given RTK may have important functional implications for its sig- naling properties, including the signal quality, duration, and magnitude (Lemmon and Schlessinger 2010; Grecco et al. 2011). The mechanisms specifying the intracellular routing of RTKs can be diverse. It appears that various ligands of the same RTK can elicit different trafficking, whereas the same ligand binding to distinct receptors can also be routed differently. This argues that the molecular determinants specifying the endocytic trafficking can be related to both ligands and receptors. Moreover, nonRTK coreceptors cooperating with the RTKs can also alter the intracellular trafficking of the ligand-receptor complexes and thus modulate the signaling output. Finally, the molecules and mechanisms that can switch the routing of a given RTK, thus regulating its signaling, are beginning to emerge.

\section{Ligand-Dependent Sorting of a Given RTK}

The best-characterized example of an RTK binding several ligands is EGFR, which associates with at least six other ligands in addition to EGF, all inducing EGFR internalization (Fig. 2A) (Harris et al. 2003). The trafficking of EGF and transforming growth factor $\alpha$ (TGF- $\alpha$ ) was studied early on, revealing the opposite actions of the two ligands: EGF causing EGFR degradation and TGF- $\alpha$ stimulating receptor recycling (Decker 1990). This is caused by different $\mathrm{pH}$ sensitivities of ligand-receptor interactions: In acidic endosomal $\mathrm{pH}$, the EGF-EGFR complex remains stable, whereas TGF- $\alpha$ dissociates from EGFR (Ebner and Derynck 1991; French et al. 1995). Recycling of TGF- $\alpha$ matches well its observed higher potency in evoking mitogenic signaling in comparison to EGF (Ebner and Derynck 1991; Waterman et al. 1998). Only very recently was the trafficking of other EGFR ligands studied in more detail (Stern et al. 2008; Baldys et al. 2009; Roepstorff et al. 2009). It was determined that similarly to EGF, heparin-binding EGF-like growth factor (HB-EGF) and $\beta$ cellulin induce EGFR degradation, whereas epiregulin and amphiregulin evoke EGFR recycling like TGF- $\alpha$ (Fig. 2A). At the mechanistic level, such differences can be correlated with the degree and duration of EGFR phosphorylation 
M. Miaczynska

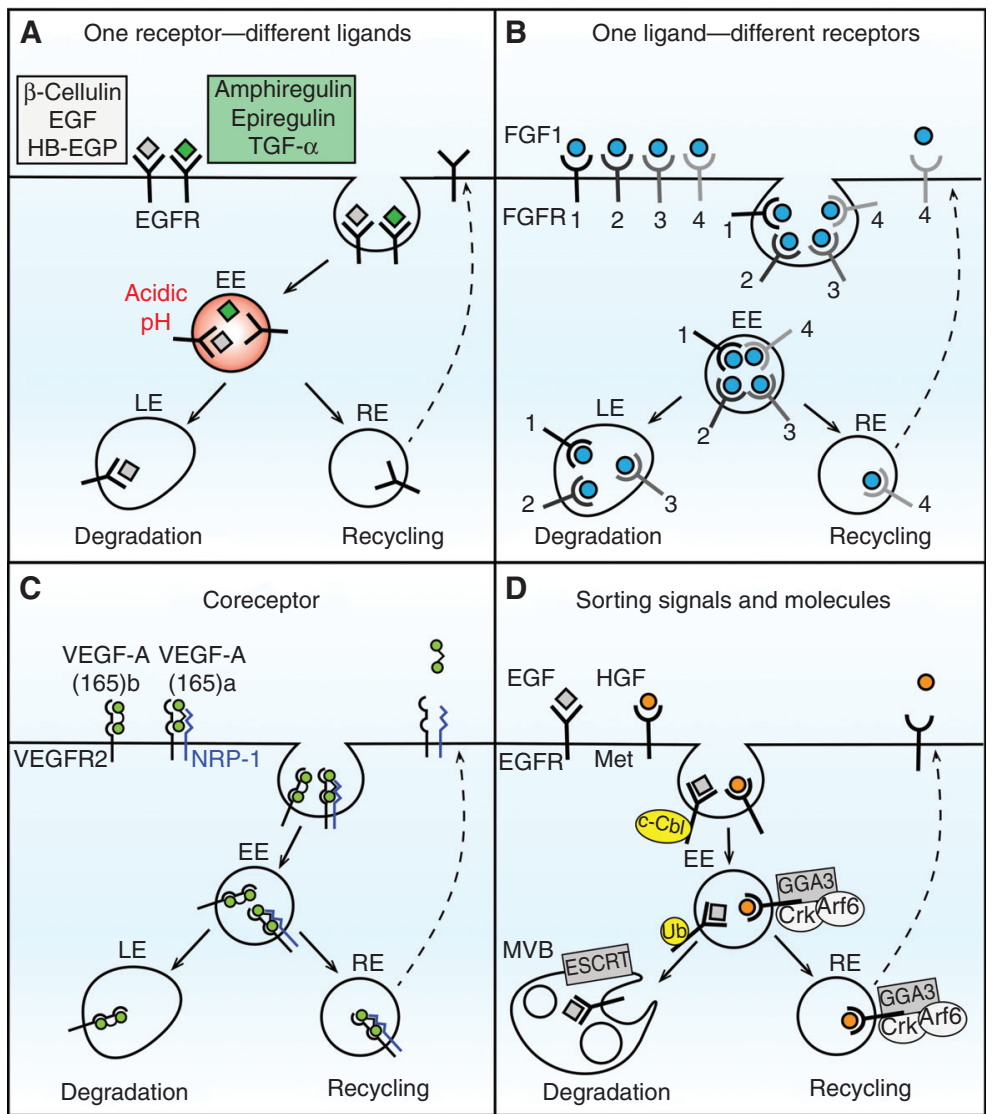

(UD), Ubiquitination; EE, early endosome; LE, late endosome; MVB, multivesicular body; $\mathrm{RE}$, recycling endosome.

Figure 2. Selected mechanisms regulating the balance between degradation and recycling of RTKs. (A) Different ligands of EGFR induce receptor degradation or recycling. Ligands sorted to degradation (listed in the white box) are stably bound to EGFR in acidic $\mathrm{pH}$ of endosomes, while recycled ligands (green box) are dissociated under these conditions. (B) Different FGF receptors are trafficked either to degradation (FGFR1-3) or recycling (FGFR4) on binding of FGF1. $(C)$ Coreceptor engagement directs trafficking of two isoforms of VEGF-A. Neuropilin-1 (NRP-1) coreceptor is involved in binding VEGF-A(165)a and causes its recycling. In contrast, it does not bind VEGF-A(165)b, which is degraded. $(D)$ Selected molecules involved in RTK sorting. Many RTKs (here exemplified by EGFR) are ubiquitinated by c-Cbl ubiquitin ligase and sorted to degradation via the ESCRT complexes. RTKs can also be recycled and in the case of Met receptor, this process is mediated by a complex of GGA3, Crk, and Arf6.

and its Cbl-mediated ubiquitination induced by various ligands (Stern et al. 2008; Baldys et al. 2009; Roepstorff et al. 2009). Similar effects were reported for FGFR2, which is degraded on action of FGF7 and recycled on stimulation with FGF10, with the latter ligand showing higher mitogenic potential (Belleudi et al. 2007). In the case of FGFR1, neural cell adhesion molecule (NCAM) was proposed to act as an uncon- ventional ligand that induces sustained FGFR1 recycling and promotes cell migration, in contrast to the natural ligand FGF2 targeting receptor for degradation (Francavilla et al. 2009).

\section{Receptor-Mediated Sorting of a Given Ligand}

It is known that one ligand can associate with several usually related RTKs. It was reported that 
FGF1, which can bind various FGFR family members, induces lysosomal degradation of FGFR1, FGFR2, and FGFR3, albeit with different efficiency (Fig. 2B). In contrast, FGFR4 is recycled on FGF1 binding, correlating with a lower degree of its ubiquitination in comparison to the other FGFRs (Haugsten et al. 2005). This may possibly cause sustained signaling downstream from FGFR4, which has been linked to poor prognosis of aggressive thyroid cancers ( $\mathrm{St}$ Bernard et al. 2005). Moreover, some RTK types can heterodimerize with related family members and such complexes may be routed differently than the homodimers. On EGF binding, the heterodimers of EGFR-ErbB2 are preferentially recycled and thus have higher mitogenic potency than the homodimers of EGFR, which are targeted largely for degradation (Lenferink et al. 1998; Worthylake et al. 1999).

\section{Coreceptor-Modulated Sorting of Ligand-RTK Complexes}

Some ligands require an additional non-RTK coreceptor to act along with the RTK for proper signaling. A striking example of how a coreceptor can modulate the RTK trafficking and signaling was reported for VEGFR2 and its coreceptor neuropilin-1 (NRP-1) (Ballmer-Hofer et al. 2011). Two splicing variants of the VEGF-A ligand have opposite effects on the VEGFR2 trafficking and signaling: Proangiogenic VEGF-A(165)a leads to receptor recycling, whereas antiangiogenic VEGF-A(165)b causes its degradation (Fig. 2C). The decisive factor determining their endocytic routing is the NRP-1 coreceptor, which is involved in binding of VEGF-A(165)a but not VEGF-A(165)b. Engagement of the coreceptor is able to direct VEGFR2 recycling through the Rab11-positive recycling compartment. This in turn enhances p38 MAPK activation, which is required for vascular sprouting and which occurs only at a low level when NRP-1 is not engaged. There is a significant number of coreceptors for RTKs (e.g., p $75^{\text {NTR }}$ neurotrophin receptor cooperating with the Trk receptors [Hempstead et al. 1991; Kaplan et al. 1991; Klein et al. 1991], GFR $\alpha$ coreceptor cooperating with Ret [Jing et al. 1996; Treanor et al. 1996], and Agrin coreceptor Lrp4 cooperating with MuSK [Kim et al. 2008; Zhang et al. 2008]). Moreover, RTKs themselves play the role of coreceptors for other receptor types (e.g., Ror2 or PTK7/Otk in Wnt signaling) (Green et al. 2008; Peradziryi et al. 2011). It is thus conceivable that the impact of coreceptors on RTK trafficking and thus signaling may be broader than currently realized.

\section{Mechanisms Determining Degradation or Recycling of RTKs and Their Impact on Signaling}

Although a given receptor may be preferentially sorted either for degradation or recycling on ligand binding, there are certain molecular mechanisms - either physiological or pathological-that may shift the balance between these endocytic routes and thus affect signaling outputs. These mechanisms involve certain sorting signals in receptors, including ubiquitination, as well as specific trafficking proteins interacting with activated receptors.

\section{RTK-Based Sorting Signals}

Regulation of RTK trafficking via receptor ubiquitination is multilayered and occurs at different transport steps. A key E3 ubiquitin ligase modifying several RTKs is c-Cbl. Although the large body of literature on this topic is reviewed elsewhere (Swaminathan and Tsygankov 2006; Acconcia et al. 2009; Eden et al. 2011), for the purpose of this review it is important to stress the role of receptor ubiquitination in sorting to multivesicular endosomes, which precedes lysosomal degradation (Fig. 2D). This process is mediated by the ESCRT (endosomal sorting complex required for transport) complexes recognizing ubiquitinated receptors and sorting them into intraluminal vesicles of multivesicular endosomes (also termed multivesicular bodies) (Falguieres et al. 2009; Raiborg and Stenmark 2009; Babst 2011; Henne et al. 2011). At this stage, the receptors become separated from the bulk of cytoplasm, and therefore are no longer capable of active signaling. It was shown that RTK mutants unable to interact with c-Cbl 
M. Miaczynska

(EGFR Y1045, Met Y1003F), thus not properly sorted for degradation, elicit enhanced mitogenic signaling (Waterman et al. 2002; Abella et al. 2005).

In addition to ubiquitination, other factors can determine the balance between degradation and recycling of RTKs. For instance, different sorting signals localized in the juxtamembrane region of two related neurotrophin receptors TrkA and TrkB direct their trafficking to recycling or degradation, respectively. In consequence, activation of TrkA induced by nerve growth factor (NGF) causes enhanced trophic response of neurons in comparison to $\operatorname{TrkB}$ stimulation with brain-derived neurotrophic factor (BDNF) (Chen et al. 2005). In the case of PDGF receptors, increased phosphorylation of PDGFR- $\beta$ caused by loss of T-cell protein tyrosine phosphatase (TC-PTP) diverts the receptor from degradation toward rapid recycling, while such an effect is not observed for the related PDGFR- $\alpha$ (Karlsson et al. 2006). In the case of Ret, alternative splicing creates two protein variants differing in their carboxyl termini (Ret9 and Ret51), which show distinct signaling and developmental roles. These differences were attributed to the unique trafficking properties of the two isoforms, both in terms of their de novo delivery to the plasma membrane and their internalization/recycling kinetics (Richardson et al. 2012).

Even more striking, mutations in a given RTK can change its intracellular trafficking, as shown for two activating Met mutants M1268T and D1246N found in human papillary renal carcinomas (Jeffers et al. 1997; Schmidt et al. 1997). Apart from being constitutively active, these mutants are degradation impaired and show increased rates of internalization and recycling both in the presence or absence of a ligand (Joffre et al. 2011). This leads to enhanced signaling and cell transformation manifested in vitro and in vivo. Importantly, blocking dynamin-dependent endocytosis inhibits migration and anchorage-independent growth of cells expressing either of the mutants as well as the ability of these cells to form tumors in nude mice (Joffre et al. 2011). These data argue that tumorigenic Met signaling is emitted mainly from in- tracellular compartments rather than from the plasma membrane. Moreover, modulating endocytic trafficking could be considered as a potential therapeutic strategy in some tumor types.

\section{Proteins Sorting RTKS}

With respect to sorting proteins directing the intracellular traffic of RTKs, recent work identified GGA3 (Golgi-localized $\gamma$-ear-containing Arf-binding protein 3) as a key factor mediating recycling of Met independently of its ubiquitination status (Fig. 2D) (Parachoniak et al. 2011). GGA3 along with Arf6-GTP and the Crk adaptor form a complex with activated Met, which sorts the receptor to Rab4-positive recycling endosomes. GGA3 depletion increases Met degradation on HGF stimulation, which impairs MAPK activation and cell migration (Parachoniak et al. 2011). However, this role of GGA3 is not universal, as another study showed that GGA3 depletion increased endosomal accumulation of EGFR and impaired its degradation (Puertollano and Bonifacino 2004). This was attributed to improper ESCRT- and ubiquitindependent sorting of EGFR to multivesicular endosomes in the absence of GGA3, which normally interacts with both ubiquitin and the ESCRT-I component Tsg101. These data argue that individual RTKs may use the same sorting adaptors for various purposes. This could be possibly achieved by RTK-dependent modification of such adaptors and indeed phosphorylation of GGA3 was reported to occur on EGFR activation and to regulate its association with membranes of intracellular organelles (Kametaka et al. 2005).

Similarly to the transmodulation of RTK internalization by heterologous stimuli, the balance between RTK degradation and recycling can be altered by other signaling pathways and regulatory proteins. For example, activation of PKC $\alpha$ mediates sorting of PDGFR- $\beta$ to recycling (Hellberg et al. 2009), and PKC-dependent phosphorylation of EGFR at Thr654 diverts the EGF-EGFR complexes from degradation to recycling (Bao et al. 2000). Similarly, association of EGFR with $\alpha 5 \beta 1$ integrin via Rab coupling protein (RCP) can induce EGFR recycling, 
which increases Akt activation and promotes cell migration (Caswell et al. 2008). Moreover, the activation of Src kinase can modulate trafficking of RTKs, such as EGFR or FGFR (Sandilands et al. 2007; Medts et al. 2010).

\section{THE ROLE OF ENDOSOMES AND OTHER INTRACELLULAR COMPARTMENTS IN RTK SIGNALING}

\section{Signaling Endosomes}

A possible function of endosomal compartments in the propagation of RTK signaling was proposed in the mid-1990s when activated RTKs and their associated signaling molecules were detected in isolated fractions of endosomes (Di Guglielmo et al. 1994; Grimes et al. 1996). These studies argued that RTKs can remain signaling competent postinternalization, thus their active signaling may not be limited to their residence at the plasma membrane but can also occur from the endosomes. Since then, a number of reports confirmed and extended these observations for different RTKs and also for other receptor types (reviewed in Sadowski et al. 2009; Sorkin and von Zastrow 2009; Miaczynska and Bar-Sagi 2010; Platta and Stenmark 2011). In a current view, endosomal signaling may contribute to an overall signaling output, although this contribution is not obligatory and its exact role may differ for various ligand-receptor systems. Below I will review examples of how endosomes can participate in the delivery, amplification, or compartmentalization of signals emitted by RTKs.

\section{Intracellular Signal Delivery via Endosomes}

The concept of signaling endosomes originates from neurons (Grimes et al. 1996) and these cells provide the most striking example of endosomes serving as intracellular vehicles for signal delivery. Cell survival of NGF-responsive neurons depends on signaling initiated in axon terminals by NGF binding to its receptor TrkA. Following internalization, endosomes carrying activated TrkA and associated signaling effectors undergo long-distance, cytoskeleton-mediated transport to deliver the signal in a retrograde manner to the cell body (Fig. 3A) (Howe and Mobley 2005;
Cosker et al. 2008). In this case, passive cytoplasmic diffusion along the axon would not be sufficient to propagate the signal rapidly enough and therefore active endosome-mediated transport is required (Howe 2005). Over the years, several components of NGF signaling endosomes were identified, most of which represent general endocytic machinery operating also in other cell types (Howe et al. 2001; Delcroix et al. 2003; Deinhardt et al. 2006; Lin et al. 2006; Varsano et al. 2006; Valdez et al. 2007; Wu et al. 2007; McCaffrey et al. 2009; Philippidou et al. 2011). However, there is still an ongoing debate about whether the NGF signaling endosomes represent early endosomes, macropinosomes (termed macroendosomes), or multivesicular bodies (Wu et al. 2009). Intriguingly, neurotrophin NT3 can also bind TrkA; however, in contrast to NGF it cannot elicit retrograde endosomal transport and prosurvival signaling. This phenomenon was recently explained by different sensitivities of NGF-TrkA and NT3-TrkA complexes to an acidic $\mathrm{pH}$ of endosomes (Harrington et al. 2011). Only acid-stable NGF-TrkA complexes, but not acid-labile NT3-TrkA, can initiate actin depolymerization around endosomes, which is necessary to launch their retrograde transport. These data illustrate how certain properties of ligand-RTK complexes, which primarily determine their behavior within the endocytic system, can profoundly affect the functional state of endosomes and in consequence, the overall cellular response to a given ligand.

\section{Amplification of Signals via Endosomes}

Endosomes represent a confined environment enclosing ligand-receptor complexes in a tight volume when compared with their distribution over plasma membrane and, therefore, multiple rounds of receptor activation may be favored in endosomes (Grecco et al. 2011). In addition, the components of NADPH oxidase complex on endosomes may be involved in the localized generation of reactive oxygen species (ROS), among which hydrogen peroxide can reversibly inactivate tyrosine phosphatases, thus prolonging RTK signaling (Janssen-Heininger et al. 
M. Miaczynska

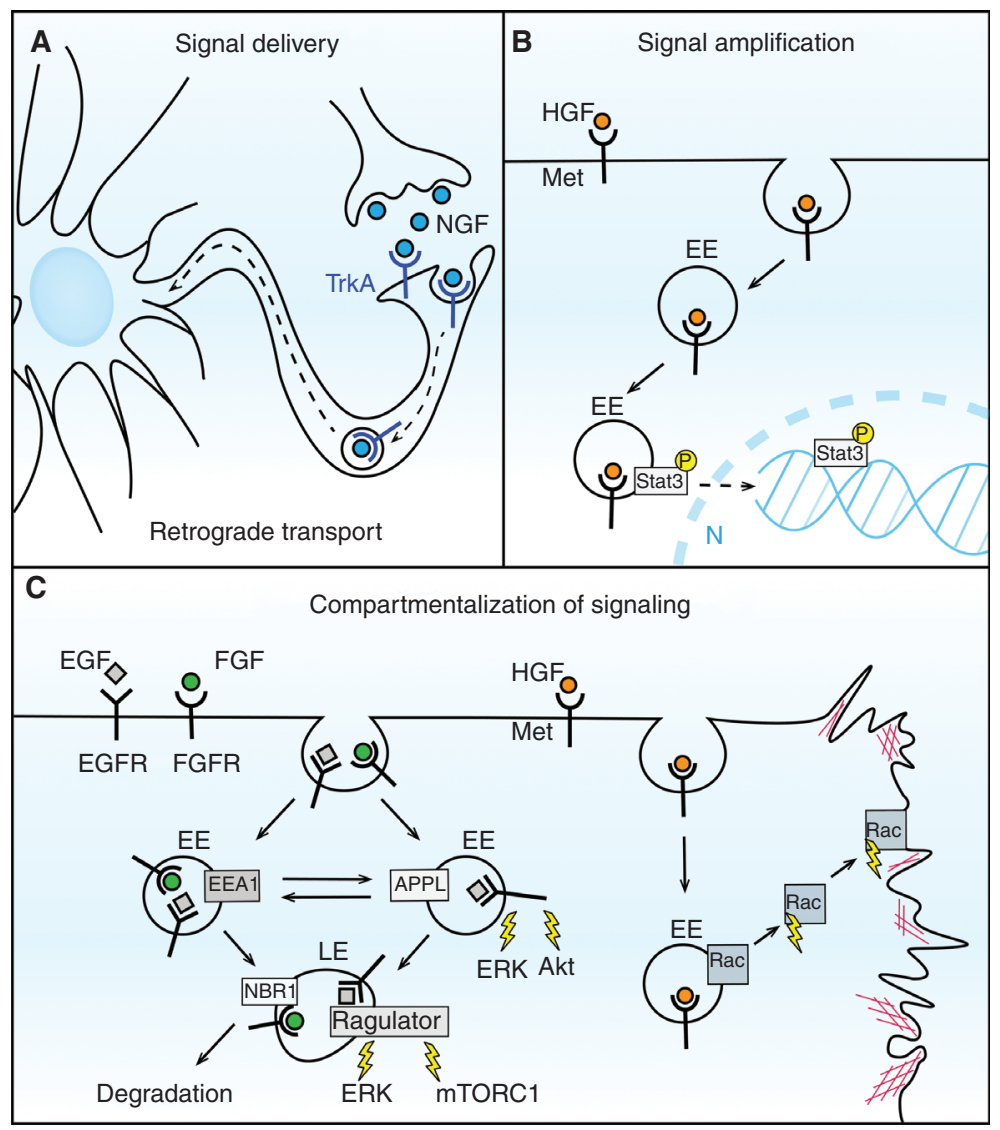

Actin; , activation; $\mathbb{P}$, phosphorylation; EE, early endosome; LE, late

endosome; $\mathrm{N}$, nucleus.

Figure 3. Mechanisms by which endosomes participate in signaling. (A) Endosomes in neurons deliver NGFTrkA signaling complexes from axon terminals to the cell body. (B) On HGF stimulation, phosphorylation and nuclear translocation of Stat 3 can occur efficiently only if activated Met receptors are transported via endosomes to the perinuclear region of the cell, thus amplifying weak signals. $(C)$ Different populations of endosomes serve as platforms for activation of various signaling molecules. APPL endosomes participate in ERK and Akt signaling. Late endosomes carry NBR1 protein involved in FGF signaling and the Ragulator complex mediating mTORC1 and ERK signaling. On HGF stimulation Rac is activated on endosomes and subsequently recycled to the plasma membrane to stimulate the formation of migratory protrusions. See text for details.

2008; Oakley et al. 2009). Another mode of signal amplification involves endosome-based delivery of activated RTKs into the perinuclear region of the cell. This should enhance weak phosphorylation of transcription factors that would otherwise be destroyed by phosphatases during long-distance cytoplasmic diffusion (Fig. 3B). Such a mechanism was proposed for Stat3, weakly activated by HGF, for which phosphorylation and subsequent nuclear transloca- tion was observed only if activated Met receptor was localized on perinuclear endosomes (Kermorgant and Parker 2008). In contrast, robust Stat 3 activation by the cytokine oncostatin-M did not require endosomal transport of its receptor. This argues that the localized endosomebased amplification is required only for weak signals. Finally, although not yet shown for RTKs, it is conceivable that multivesicular endosomes could contribute to signal amplification 
by sequestering in their intraluminal vesicles some negative cytoplasmic regulators of RTK signaling. Such a precedent was reported for the Wnt signaling, in which the inhibitory enzyme GSK3 is removed from the cytoplasm and entrapped within endosomes on Wnt stimulation, thus contributing to enhanced signaling (Taelman et al. 2010).

\section{Compartmentalization of Signaling in Endosomes}

Recent progress in the field of endocytosis indicates that the common classification of endosomes into early, late, and recycling is oversimplified, as cells harbor many subpopulations of endosomes, some of which may be cell-typespecific (Perret et al. 2005; Bokel et al. 2006; Zoncu et al. 2009). These endosomal compartments differ in their protein and lipid composition, dynamics, and function, therefore, cargo transported between them encounters different environments at subsequent trafficking steps. Several signaling components are localized on specific endosomes, thus enabling active signal propagation only when the activated receptor reaches a particular compartment (Sadowski et al. 2009; Platta and Stenmark 2011). For RTK signaling, one of the earliest examples of endosome-specific components was the scaffolding complex composed of MP1, p14 and p18, which tethers MEK1 to late endosomes and is required for full ERK activation on EGF stimulation (Teis et al. 2002, 2006; Nada et al. 2009). More recently, the same complex (now named Ragulator) was reported to activate mTORC1 (mammalian target of rapamycin complex 1) by recruiting it to lysosomes in response to amino acids (Fig. 3C) (Sancak et al. 2010). These findings open the possibility for direct cross talk between RTK-dependent ERK activation and mTOR signaling occurring on the late endosome/lysosome membrane. Another late endosomal protein NBR1 was shown to interact with an inhibitor of FGF signaling Spred2, thus participating in down-regulation of FGFR1 (Fig. 3C) (Mardakheh et al. 2009).

Various types of early endosomes can also serve as platforms for assembly of RTK signaling complexes, partly different from those formed at the plasma membrane (Burke et al. 2001). APPL endosomes, a subpopulation of early endosomes, were shown to participate in transport and signaling of EGF and NGF (Fig. 3C) (Miaczynska et al. 2004a; Lin et al. 2006; Varsano et al. 2006; Zoncu et al. 2009). Prolonged residence of EGFR in APPL endosomes increased activation of ERK and Akt (Zoncu et al. 2009), whereas depletion of APPL1 prevented their activation on NGF stimulation, thus inhibiting neurite outgrowth (Lin et al. 2006; Varsano et al. 2006). In zebrafish development, APPL endosomes transmit prosurvival signals by controlling the activity of Akt and its substrate specificity toward GSK3 $\beta$ but not TSC2 (Schenck et al. 2008).

Finally, endosomes enable compartmentalized signaling to direct cell migration, as shown by activation of Rac on early endosomes on HGF stimulation (Palamidessi et al. 2008). Activated Rac is subsequently recycled to specific microdomains on the plasma membrane to stimulate localized formation of migratory protrusions (Fig. 3C).

The Role of Endoplasmic Reticulum in Modulating RTK Signaling

In addition to the endosomal compartments, the organelles of the secretory pathway, in particular endoplasmic reticulum (ER), can also contribute to the modulation of RTK signaling by various mechanisms. First, ER-based ubiquitination and degradation mechanisms can regulate the levels of nascent RTKs eventually targeted to the plasma membrane, as recently shown for ErbB3 levels controlled by the E3 ubiquitin ligase Nrdp1 at the ER (Fry et al. 2011). Second, ER-localized protein tyrosine phosphatase PTP1B plays multiple roles in inactivating ligand-bound RTKs after internalization and in modulating their endocytic trafficking (Stuible and Tremblay 2010; Sangwan et al. 2011). A recent identification of direct contact sites between endosomes and ER provides a conceptual framework of how an ER-tethered enzyme can affect the function of RTKs on the endosomal membranes (Fig. 4A) (Eden et al. 2010). Third, there are cases of ER-specific ab- 
M. Miaczynska

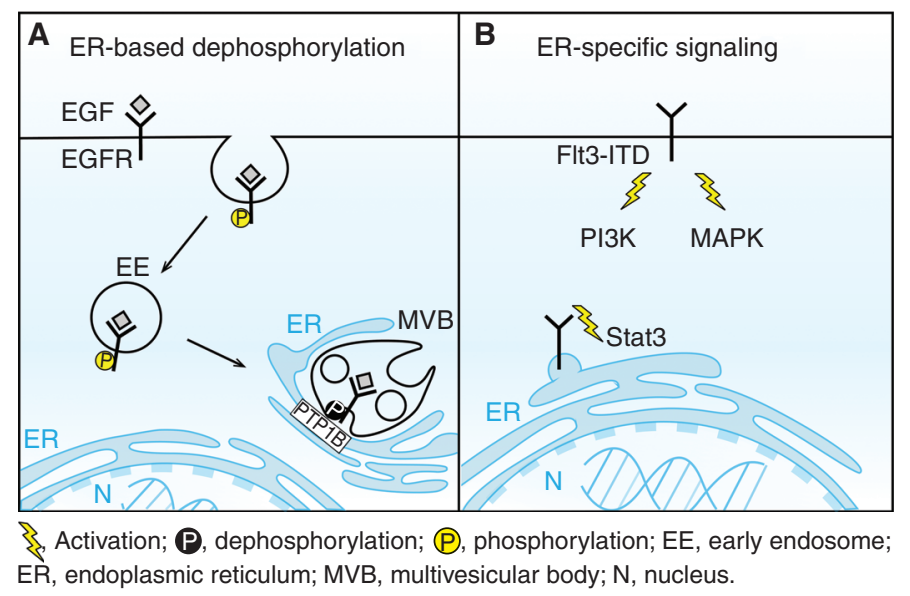

Figure 4. The role of endoplasmic reticulum (ER) in modulating RTK signaling. ( $A$ ) Direct contact sites between endosomes and the ER enable dephosphorylation of internalized RTKs by protein tyrosine phosphatase PTP1B localized on the ER membrane. $(B)$ Constitutively active oncogenic mutant of Flt3 receptor (Flt3-ITD) activates different downstream effectors when localized in the ER or at the plasma membrane.

errant signaling elicited by oncogenic RTKs, as reported for the Flt3 mutant containing internal tandem duplication (Flt3-ITD), which causes its ligand-independent activation and predominant retention in the ER (Schmidt-Arras et al. 2005). Flt3-ITD is not only constitutively active in the ER but the pattern of tyrosine phosphorylation of the receptor and the set of activated downstream effectors are different from those observed for the wild-type Flt3 at the plasma membrane (Fig. 4B) (Choudhary et al. 2009). This argues that, at least under pathological conditions, ER can contribute to the overall signaling of a given RTK in a compartment-specific manner. It is further possible that, like ER, the Golgi apparatus may also play similar roles in the regulation of RTK signaling and trafficking, as reported for VEGFR1 and VEGFR2 (Mittar et al. 2009; Manickam et al. 2011).

\section{Microvesicles for Extracellular Propagation of RTK Signals}

Accumulating studies report that cells, in particular tumor cells, can release several types of microvesicles into the environment (reviewed in Lee et al. 2011). These vesicles are either of endosomal origins (produced on fusion of multivesicular endosomes with the plasma membrane as so-called exosomes [Lakkaraju and Rodriguez-Boulan 2008; Simons and Raposo 2009]) or can be produced by other mechanisms. They function as a means of communication among cells by exchanging proteins, lipids, and nucleic acids, as well as contributing to pathogen spread and immune surveillance. Microvesicles were shown to contain, among others, RTKs and their ligands (Lee et al. 2011). In human glioma cells, microvesicles termed oncosomes carried an oncogenic form of EGFR (EGFRvIII), which was incorporated into the membrane of recipient cells, contributing to their transformation and tumor spread (Al-Nedawi et al. 2008; Skog et al. 2008). Still, the exact mechanisms and the prevalence of this phenomenon need to be further investigated.

\section{CONCLUDING REMARKS}

As evident from this overview, the control of RTK signaling by intracellular trafficking is complex and occurs at multiple levels. Abundant evidence indicates that this regulation is of physiological importance in vivo, both during development and in adult tissues. Importantly, trafficking of RTKs can be modulated by non-RTK signaling pathways, providing a mechanism for pathway cross talk and coordi- 
nated regulation of cellular responses to various stimuli. Moreover, aberrant RTK trafficking can be oncogenic (Lanzetti and Di Fiore 2008; Mosesson et al. 2008; Abella and Park 2009), indicating that future therapeutic approaches could be directed to correct such defects.

Finally, as argued here, regulation of signaling by trafficking is important but the reverse is also true. RTK signaling affects the trafficking machinery, for example, to drive ligand-induced endocytosis and then intracellular sorting of RTKs, although the underlying molecular mechanisms are still poorly known. Much remains to be discovered on how activated RTKs may modify endocytic proteins, changing their activity or localization. Recent data indicate that different signaling pathways exert feedback control over the morphology and function of endosomal compartments (Collinet et al. 2010) but the knowledge of detailed mechanisms is missing. As currently the signaling and trafficking fields are integrated more than ever before, we are bound to face exciting progress and discover further principles of coordinated regulation between signal transduction and membrane transport of RTKs and other receptor types.

\section{ACKNOWLEDGMENTS}

I thank Dr. Anna Hupalowska for preparing the figures and the members of my group for a critical reading of the manuscript. Research in my laboratory is supported by the National Science Centre (MAESTRO grant 2011/02/A/NZ3/ 00149 and grant No. N301 296437), by a grant from Switzerland through the Swiss contribution to the enlarged European Union (PolishSwiss Research Programme project PSPB-094/ 2010), and by the European Union FP7 grant FishMed GA No. 316125.

\section{REFERENCES}

Abella JV, Park M. 2009. Breakdown of endocytosis in the oncogenic activation of receptor tyrosine kinases. Am J Physiol Endocrinol Metab 296: E973-E984.

Abella JV, Peschard P, Naujokas MA, Lin T, Saucier C, Urbe S, Park M. 2005. Met/Hepatocyte growth factor receptor ubiquitination suppresses transformation and is required for Hrs phosphorylation. Mol Cell Biol 25: 9632-9645.
Abella JV, Parachoniak CA, Sangwan V, Park M. 2010a. Dorsal ruffle microdomains potentiate Met receptor tyrosine kinase signaling and down-regulation. J Biol Chem 285: 24956-24967.

Abella JV, Vaillancourt R, Frigault MM, Ponzo MG, Zuo D, Sangwan V, Larose L, Park M. 2010b. The Gab1 scaffold regulates RTK-dependent dorsal ruffle formation through the adaptor Nck. J Cell Sci 123: 1306-1319.

Acconcia F, Sigismund S, Polo S. 2009. Ubiquitin in trafficking: The network at work. Exp Cell Res 315: 1610-1618.

Al-Nedawi K, Meehan B, Micallef J, Lhotak V, May L, Guha A, Rak J. 2008. Intercellular transfer of the oncogenic receptor EGFRvIII by microvesicles derived from tumour cells. Nat Cell Biol 10: 619-624.

Assaker G, Ramel D, Wculek SK, Gonzalez-Gaitan M, Emery G. 2010. Spatial restriction of receptor tyrosine kinase activity through a polarized endocytic cycle controls border cell migration. Proc Natl Acad Sci 107: 22558-22563.

Babst M. 2011. MVB vesicle formation: ESCRT-dependent, ESCRT-independent and everything in between. Curr Opin Cell Biol 23: 452-457.

Baldys A, Gooz M, Morinelli TA, Lee MH, Raymond JR Jr, Luttrell LM, Raymond JR Sr. 2009. Essential role of c-Cbl in amphiregulin-induced recycling and signaling of the endogenous epidermal growth factor receptor. Biochemistry 48: 1462-1473.

Ballmer-Hofer K, Andersson AE, Ratcliffe LE, Berger P. 2011. Neuropilin-1 promotes VEGFR-2 trafficking through Rab11 vesicles thereby specifying signal output. Blood 118: 816-826.

Bao J, Alroy I, Waterman H, Schejter ED, Brodie C, Gruenberg J, Yarden Y. 2000. Threonine phosphorylation diverts internalized epidermal growth factor receptors from a degradative pathway to the recycling endosome. J Biol Chem 275: 26178-26186.

Beguinot L, Hanover JA, Ito S, Richert ND, Willingham MC, Pastan I. 1985. Phorbol esters induce transient internalization without degradation of unoccupied epidermal growth factor receptors. Proc Natl Acad Sci 82: 27742778.

Belleudi F, Leone L, Nobili V, Raffa S, Francescangeli F, Maggio M, Morrone S, Marchese C, Torrisi MR. 2007. Keratinocyte growth factor receptor ligands target the receptor to different intracellular pathways. Traffic 8: 1854-1872.

Belleudi F, Scrofani C, Torrisi MR, Mancini P. 2011. Polarized endocytosis of the keratinocyte growth factor receptor in migrating cells: Role of SRC-signaling and cortactin. PLoS ONE 6: e29159.

Bokel C, Schwabedissen A, Entchev E, Renaud O, GonzalezGaitan M. 2006. Sara endosomes and the maintenance of Dpp signaling levels across mitosis. Science 314: 11351139.

Brankatschk B, Wichert SP, Johnson SD, Schaad O, Rossner MJ, Gruenberg J. 2012. Regulation of the EGF transcriptional response by endocytic sorting. Sci Signal 5: ra21.

Bremm A, Walch A, Fuchs M, Mages J, Duyster J, Keller G, Hermannstadter C, Becker KF, Rauser S, Langer R, et al. 2008. Enhanced activation of epidermal growth factor receptor caused by tumor-derived E-cadherin mutations. Cancer Res 68: 707-714. 
M. Miaczynska

Bryant DM, Wylie FG, Stow JL. 2005. Regulation of endocytosis, nuclear translocation, and signaling of fibroblast growth factor receptor 1 by E-cadherin. Mol Biol Cell 16: $14-23$

Burke P, Schooler K, Wiley HS. 2001. Regulation of epidermal growth factor receptor signaling by endocytosis and intracellular trafficking. Mol Biol Cell 12: 1897-1910.

Caswell PT, Chan M, Lindsay AJ, McCaffrey MW, Boettiger D, Norman JC. 2008. Rab-coupling protein coordinates recycling of $\alpha 5 \beta 1$ integrin and EGFR1 to promote cell migration in 3D microenvironments. J Cell Biol 183: $143-155$.

Cavalli V, Vilbois F, Corti M, Marcote MJ, Tamura K, Karin M, Arkinstall S, Gruenberg J. 2001. The stress-induced MAP kinase 38 regulates endocytic trafficking via the GDI:Rab5 complex. Mol Cell 7: 421-432.

Champion KJ, Guinea M, Dammai V, Hsu T. 2008. Endothelial function of von Hippel-Lindau tumor suppressor gene: Control of fibroblast growth factor receptor signaling. Cancer Res 68: 4649-4657.

Chen ZY, Ieraci A, Tanowitz M, Lee FS. 2005. A novel endocytic recycling signal distinguishes biological responses of Trk neurotrophin receptors. Mol Biol Cell 16: 5761-5772.

Choudhary C, Olsen JV, Brandts C, Cox J, Reddy PN, Bohmer FD, Gerke V, Schmidt-Arras DE, Berdel WE, MullerTidow C, et al. 2009. Mislocalized activation of oncogenic RTKs switches downstream signaling outcomes. Mol Cell 36: 326-339.

Collinet C, Stoter M, Bradshaw CR, Samusik N, Rink JC, Kenski D, Habermann B, Buchholz F, Henschel R, Mueller MS, et al. 2010. Systems survey of endocytosis by multiparametric image analysis. Nature 464: 243-249.

Conner SD, Schmid SL. 2003. Regulated portals of entry into the cell. Nature 422: 37-44.

Cosker KE, Courchesne SL, Segal RA. 2008. Action in the axon: Generation and transport of signaling endosomes. Curr Opin Neurobiol 18: 270-275.

Decker SJ. 1990. Epidermal growth factor and transforming growth factor- $\alpha$ induce differential processing of the epidermal growth factor receptor. Biochem Biophys Res Commun 166: 615-621.

De Donatis A, Comito G, Buricchi F, Vinci MC, Parenti A, Caselli A, Camici G, Manao G, Ramponi G, Cirri P. 2008. Proliferation versus migration in platelet-derived growth factor signaling: The key role of endocytosis. J Biol Chem 283: 19948-19956.

Deinhardt K, Salinas S, Verastegui C, Watson R, Worth D, Hanrahan S, Bucci C, Schiavo G. 2006. Rab5 and Rab7 control endocytic sorting along the axonal retrograde transport pathway. Neuron 52: 293-305.

Delcroix JD, Valletta JS, Wu C, Hunt SJ, Kowal AS, Mobley WC. 2003. NGF signaling in sensory neurons: Evidence that early endosomes carry NGF retrograde signals. Neuron 39: 69-84.

Delva E, Kowalczyk AP. 2009. Regulation of cadherin trafficking. Traffic 10: 259-267.

Di Guglielmo GM, Baass PC, Ou WJ, Posner BI, Bergeron JJ. 1994. Compartmentalization of SHC, GRB2 and mSOS, and hyperphosphorylation of Raf-1 by EGF but not insulin in liver parenchyma. EMBO J 13: 4269-4277.
Di Guglielmo GM, Le Roy C, Goodfellow AF, Wrana JL. 2003. Distinct endocytic pathways regulate TGF- $\beta$ receptor signalling and turnover. Nat Cell Biol 5: 410-421.

Disanza A, Frittoli E, Palamidessi A, Scita G. 2009. Endocytosis and spatial restriction of cell signaling. Mol Oncol 3: $280-296$.

Ebner R, Derynck R. 1991. Epidermal growth factor and transforming growth factor- $\alpha$ : Differential intracellular routing and processing of ligand-receptor complexes. Cell Regul 2: 599-612.

Eden ER, White IJ, Tsapara A, Futter CE. 2010. Membrane contacts between endosomes and ER provide sites for PTP1B-epidermal growth factor receptor interaction. Nat Cell Biol 12: 267-272.

Eden ER, Huang F, Sorkin A, Futter CE. 2012. The role of EGF receptor ubiquitination in regulating its intracellular traffic. Traffic 13: 329-337.

Elfenbein A, Lanahan A, Zhou TX, Yamasaki A, Tkachenko E, Matsuda M, Simons M. 2012. Syndecan 4 regulates FGFR1 signaling in endothelial cells by directing macropinocytosis. Sci Signal 5: ra36.

Falguieres T, Luyet PP, Gruenberg J. 2009. Molecular assemblies and membrane domains in multivesicular endosome dynamics. Exp Cell Res 315: 1567-1573.

Francavilla C, Cattaneo P, Berezin V, Bock E, Ami D, de Marco A, Christofori G, Cavallaro U. 2009. The binding of NCAM to FGFR1 induces a specific cellular response mediated by receptor trafficking. J Cell Biol 187: 11011116.

French AR, Sudlow GP, Wiley HS, Lauffenburger DA. 1994. Postendocytic trafficking of epidermal growth factor-receptor complexes is mediated through saturable and specific endosomal interactions. J Biol Chem 269: 1574915755.

French AR, Tadaki DK, Niyogi SK, Lauffenburger DA. 1995. Intracellular trafficking of epidermal growth factor family ligands is directly influenced by the $\mathrm{pH}$ sensitivity of the receptor/ligand interaction. J Biol Chem 270: 43344340.

Fry WH, Simion C, Sweeney C, Carraway KL 3rd. 2011. Quantity control of the ErbB3 receptor tyrosine kinase at the endoplasmic reticulum. Mol Cell Biol 31: 30093018.

Goldoni S, Iozzo RV. 2008. Tumor microenvironment: Modulation by decorin and related molecules harboring leucine-rich tandem motifs. Int J Cancer 123: 24732479.

Goldoni S, Humphries A, Nystrom A, Sattar S, Owens RT, McQuillan DJ, Ireton K, Iozzo RV. 2009. Decorin is a novel antagonistic ligand of the Met receptor. J Cell Biol 185: 743-754.

Grecco HE, Schmick M, Bastiaens PI. 2011. Signaling from the living plasma membrane. Cell 144: 897-909.

Green JL, Kuntz SG, Sternberg PW. 2008. Ror receptor tyrosine kinases: Orphans no more. Trends Cell Biol 18: 536-544.

Grimes ML, Zhou J, Beattie EC, Yuen EC, Hall DE, Valletta JS, Topp KS, LaVail JH, Bunnett NW, Mobley WC. 1996. Endocytosis of activated TrkA: Evidence that nerve growth factor induces formation of signaling endosomes. J Neurosci 16: 7950-7964. 
Gur G, Rubin C, Katz M, Amit I, Citri A, Nilsson J, Amariglio N, Henriksson R, Rechavi G, Hedman $\mathrm{H}$, et al. LRIG1 restricts growth factor signaling by enhancing receptor ubiquitylation and degradation. $E M B O J$ 23: 3270-3281.

Harrington AW, St Hillaire C, Zweifel LS, Glebova NO, Philippidou P, Halegoua S, Ginty DD. 2011. Recruitment of actin modifiers to TrkA endosomes governs retrograde NGF signaling and survival. Cell 146: 421-434.

Harris RC, Chung E, Coffey RJ. 2003. EGF receptor ligands. Exp Cell Res 284: 2-13.

Haugsten EM, Sorensen V, Brech A, Olsnes S, Wesche J. 2005. Different intracellular trafficking of FGF1 endocytosed by the four homologous FGF receptors. J Cell Sci 118: $3869-3881$.

Heldin CH, Wasteson A, Westermark B. 1982. Interaction of platelet-derived growth factor with its fibroblast receptor. Demonstration of ligand degradation and receptor modulation. J Biol Chem 257: 4216-4221.

Hellberg C, Schmees C, Karlsson S, Ahgren A, Heldin CH. 2009. Activation of protein kinase $\mathrm{C} \alpha$ is necessary for sorting the PDGF $\beta$-receptor to Rab4a-dependent recycling. Mol Biol Cell 20: 2856-2863.

Hempstead BL, Martin-Zanca D, Kaplan DR, Parada LF, Chao MV. 1991. High-affinity NGF binding requires coexpression of the trk proto-oncogene and the low-affinity NGF receptor. Nature 350: 678-683.

Henne WM, Buchkovich NJ, Emr SD. 2011. The ESCRT pathway. Dev Cell 21: 77-91.

Howe CL. 2005. Modeling the signaling endosome hypothesis: Why a drive to the nucleus is better than a (random) walk. Theor Biol Med Model 2: 43.

Howe CL, Mobley WC. 2005. Long-distance retrograde neurotrophic signaling. Curr Opin Neurobiol 15: 40-48.

Howe CL, Valletta JS, Rusnak AS, Mobley WC. 2001. NGF signaling from clathrin-coated vesicles: Evidence that signaling endosomes serve as a platform for the Ras-MAPK pathway. Neuron 32: 801-814.

Howes MT, Mayor S, Parton RG. 2010. Molecules, mechanisms, and cellular roles of clathrin-independent endocytosis. Curr Opin Cell Biol 22: 519-527.

Hsu T, Adereth Y, Kose N, Dammai V. 2006. Endocytic function of von Hippel-Lindau tumor suppressor protein regulates surface localization of fibroblast growth factor receptor 1 and cell motility. J Biol Chem 281: 12069 12080.

Janssen-Heininger YM, Mossman BT, Heintz NH, Forman HJ, Kalyanaraman B, Finkel T, Stamler JS, Rhee SG, van der Vliet A. 2008. Redox-based regulation of signal transduction: Principles, pitfalls, and promises. Free Radic Biol Med 45: 1-17.

Jeffers M, Schmidt L, Nakaigawa N, Webb CP, Weirich G, Kishida T, Zbar B, Vande Woude GF. 1997. Activating mutations for the met tyrosine kinase receptor in human cancer. Proc Natl Acad Sci 94: 11445-11450.

Jekely G, Sung HH, Luque CM, Rorth P. 2005. Regulators of endocytosis maintain localized receptor tyrosine kinase signaling in guided migration. Dev Cell 9: 197-207.

Jiang X, Sorkin A. 2003. Epidermal growth factor receptor internalization through clathrin-coated pits requires $\mathrm{Cbl}$
RING finger and proline-rich domains but not receptor polyubiquitylation. Traffic 4: 529-543.

Jing S, Wen D, Yu Y, Holst PL, Luo Y, Fang M, Tamir R, Antonio L, Hu Z, Cupples R, et al. 1996. GDNF-induced activation of the ret protein tyrosine kinase is mediated by GDNFR- $\alpha$, a novel receptor for GDNF. Cell 85: 1113 1124.

Joffre C, Barrow R, Menard L, Calleja V, Hart IR, Kermorgant S. 2011. A direct role for Met endocytosis in tumorigenesis. Nat Cell Biol 13: 827-837.

Kametaka S, Mattera R, Bonifacino JS. 2005. Epidermal growth factor-dependent phosphorylation of the GGA3 adaptor protein regulates its recruitment to membranes. Mol Cell Biol 25: 7988-8000.

Kaplan DR, Hempstead BL, Martin-Zanca D, Chao MV, Parada LF. 1991. The trk proto-oncogene product: A signal transducing receptor for nerve growth factor. Science 252: $554-558$.

Karlsson S, Kowanetz K, Sandin A, Persson C, Ostman A, Heldin CH, Hellberg C. 2006. Loss of T-cell protein tyrosine phosphatase induces recycling of the plateletderived growth factor (PDGF) $\beta$-receptor but not the PDGF $\alpha$-receptor. Mol Biol Cell 17: 4846-4855.

Kazazic M, Roepstorff K, Johannessen LE, Pedersen NM, van Deurs B, Stang E, Madshus IH. 2006. EGF-induced activation of the EGF receptor does not trigger mobilization of caveolae. Traffic 7: 1518-1527.

Kermorgant S, Parker PJ. 2008. Receptor trafficking controls weak signal delivery: A strategy used by c-Met for STAT3 nuclear accumulation. J Cell Biol 182: 855-863.

Kerr MC, Teasdale RD. 2009. Defining macropinocytosis. Traffic 10: 364-371.

Kim N, Stiegler AL, Cameron TO, Hallock PT, Gomez AM, Huang JH, Hubbard SR, Dustin ML, Burden SJ. 2008. Lrp4 is a receptor for Agrin and forms a complex with MuSK. Cell 135: 334-342.

Klein R, Jing SQ, Nanduri V, O'Rourke E, Barbacid M. 1991. The trk proto-oncogene encodes a receptor for nerve growth factor. Cell 65: 189-197.

Laederich MB, Funes-Duran M, Yen L, Ingalla E, Wu X, Carraway KL 3rd, Sweeney C. 2004. The leucine-rich repeat protein LRIG1 is a negative regulator of ErbB family receptor tyrosine kinases. J Biol Chem 279: 47050-47056.

Lakkaraju A, Rodriguez-Boulan E. 2008. Itinerant exosomes: Emerging roles in cell and tissue polarity. Trends Cell Biol 18: 199-209.

Lampugnani MG, Orsenigo F, Gagliani MC, Tacchetti C, Dejana E. 2006. Vascular endothelial cadherin controls VEGFR-2 internalization and signaling from intracellular compartments. J Cell Biol 174: 593-604.

Lanzetti L, Di Fiore PP. 2008. Endocytosis and cancer: An "insider" network with dangerous liaisons. Traffic 9: 2011-2021.

Lee TH, D’Asti E, Magnus N, Al-Nedawi K, Meehan B, Rak J. 2011. Microvesicles as mediators of intercellular communication in cancer-The emerging science of cellular "debris." Semin Immunopathol 33: 455-467.

Lemmon MA, Schlessinger J. 2010. Cell signaling by receptor tyrosine kinases. Cell 141: 1117-1134.

Lenferink AE, Pinkas-Kramarski R, van de Poll ML, van Vugt MJ, Klapper LN, Tzahar E, Waterman H, Sela M, 
M. Miaczynska

van Zoelen EJ, Yarden Y. 1998. Differential endocytic routing of homo- and hetero-dimeric ErbB tyrosine kinases confers signaling superiority to receptor heterodimers. EMBO J 17: 3385-3397.

Le Roy C, Wrana JL. 2005. Clathrin- and non-clathrin-mediated endocytic regulation of cell signalling. Nat Rev Mol Cell Biol 6: 112-126.

Lin CR, Chen WS, Lazar CS, Carpenter CD, Gill GN, Evans RM, Rosenfeld MG. 1986. Protein kinase C phosphorylation at Thr 654 of the unoccupied EGF receptor and EGF binding regulate functional receptor loss by independent mechanisms. Cell 44: 839-848.

Lin DC, Quevedo C, Brewer NE, Bell A, Testa JR, Grimes ML, Miller FD, Kaplan DR. 2006. APPL1 associates with TrkA and GIPC1 and is required for nerve growth factormediated signal transduction. Mol Cell Biol 26: 89288941.

Lin HH, Li X, Chen JL, Sun X, Cooper FN, Chen YR, Zhang W, Chung Y, Li A, Cheng CT, et al. 2012. Identification of an AAA ATPase VPS4B-dependent pathway that modulates epidermal growth factor receptor abundance and signaling during hypoxia. Mol Cell Biol 32: 1124-1138.

Mace G, Miaczynska M, Zerial M, Nebreda AR. 2005. Phosphorylation of EEA1 by 38 MAP kinase regulates mu opioid receptor endocytosis. EMBO J 24: 3235-3246.

Manickam V, Tiwari A, Jung JJ, Bhattacharya R, Goel A, Mukhopadhyay D, Choudhury A. 2011. Regulation of vascular endothelial growth factor receptor 2 trafficking and angiogenesis by Golgi localized t-SNARE syntaxin 6 . Blood 117: 1425-1435.

Mardakheh FK, Yekezare M, Machesky LM, Heath JK. 2009. Spred2 interaction with the late endosomal protein NBR1 down-regulates fibroblast growth factor receptor signaling. J Cell Biol 187: 265-277.

Mayor S, Pagano RE. 2007. Pathways of clathrin-independent endocytosis. Nat Rev Mol Cell Biol 8: 603-612.

McCaffrey G, Welker J, Scott J, der Salm L, Grimes ML. 2009. High-resolution fractionation of signaling endosomes containing different receptors. Traffic 10: 938-950.

McMahon HT, Boucrot E. 2011. Molecular mechanism and physiological functions of clathrin-mediated endocytosis. Nat Rev Mol Cell Biol 12: 517-533.

Medts T, de Diesbach P, Cominelli A, N'Kuli F, Tyteca D, Courtoy PJ. 2010. Acute ligand-independent Src activation mimics low EGF-induced EGFR surface signalling and redistribution into recycling endosomes. Exp Cell Res 316: 3239-3253.

Mellman I, Nelson WJ. 2008. Coordinated protein sorting, targeting and distribution in polarized cells. Nat Rev Mol Cell Biol 9: 833-845.

Miaczynska M, Bar-Sagi D. 2010. Signaling endosomes: Seeing is believing. Curr Opin Cell Biol 22: 535-540.

Miaczynska M, Christoforidis S, Giner A, Shevchenko A, Uttenweiler-Joseph S, Habermann B, Wilm M, Parton RG, Zerial M. 2004a. APPL proteins link Rab5 to nuclear signal transduction via an endosomal compartment. Cell 116: $445-456$.

Miaczynska M, Pelkmans L, Zerial M. 2004b. Not just a sink: Endosomes in control of signal transduction. Curr Opin Cell Biol 16: 400-406.
Mittar S, Ulyatt C, Howell GJ, Bruns AF, Zachary I, Walker JH, Ponnambalam S. 2009. VEGFR1 receptor tyrosine kinase localization to the Golgi apparatus is calcium-dependent. Exp Cell Res 315: 877-889.

Mosesson Y, Mills GB, Yarden Y. 2008. Derailed endocytosis: An emerging feature of cancer. Nat Rev Cancer 8: 835850.

Mukherjee S, Tessema M, Wandinger-Ness A. 2006. Vesicular trafficking of tyrosine kinase receptors and associated proteins in the regulation of signaling and vascular function. Circ Res 98: 743-756.

Nada S, Hondo A, Kasai A, Koike M, Saito K, Uchiyama Y, Okada M. 2009. The novel lipid raft adaptor 18 controls endosome dynamics by anchoring the MEK-ERK pathway to late endosomes. EMBO J 28: 477-489.

Naka D, Shimomura T, Yoshiyama Y, Sato M, Ishii T, Hara H. 1993. Internalization and degradation of hepatocyte growth factor in hepatocytes with down-regulation of the receptor/c-Met. FEBS Lett 329: 147-152.

Nakayama M, Nakayama A, van Lessen M, Yamamoto $H$, Hoffmann S, Drexler HC, Itoh N, Hirose T, Breier G, Vestweber D, et al. 2013. Spatial regulation of VEGF receptor endocytosis in angiogenesis. Nat Cell Biol 15: $249-260$.

Norambuena A, Metz C, Jung JE, Silva A, Otero C, Cancino J, Retamal C, Valenzuela JC, Soza A, Gonzalez A. 2010. Phosphatidic acid induces ligand-independent epidermal growth factor receptor endocytic traffic through PDE4 activation. Mol Biol Cell 21: 2916-2929.

Oakley FD, Abbott D, Li Q, Engelhardt JF. 2009. Signaling components of redox active endosomes: The redoxosomes. Antioxid Redox Signal 11: 1313-1333.

Orian-Rousseau V, Ponta H. 2008. Adhesion proteins meet receptors: A common theme? Adv Cancer Res 101: 6392.

Orth JD, Krueger EW, Weller SG, McNiven MA. 2006. A novel endocytic mechanism of epidermal growth factor receptor sequestration and internalization. Cancer Res 66: 3603-3610.

Palamidessi A, Frittoli E, Garre M, Faretta M, Mione M, Testa I, Diaspro A, Lanzetti L, Scita G, Di Fiore PP. 2008. Endocytic trafficking of Rac is required for the spatial restriction of signaling in cell migration. Cell 134: 135-147.

Parachoniak CA, Luo Y, Abella JV, Keen JH, Park M. 2011. GGA3 functions as a switch to promote Met receptor recycling, essential for sustained ERK and cell migration. Dev Cell 20: 751-763.

Pasquale EB. 2008. Eph-ephrin bidirectional signaling in physiology and disease. Cell 133: 38-52.

Pelkmans L, Fava E, Grabner H, Hannus M, Habermann B, Krausz E, Zerial M. 2005. Genome-wide analysis of human kinases in clathrin- and caveolae/raft-mediated endocytosis. Nature 436: 78-86.

Peradziryi H, Kaplan NA, Podleschny M, Liu X, Wehner P, Borchers A, Tolwinski NS. 2011. PTK7/Otk interacts with Wnts and inhibits canonical Wnt signalling. EMBO J 30: 3729-3740.

Perret E, Lakkaraju A, Deborde S, Schreiner R, RodriguezBoulan E. 2005. Evolving endosomes: How many varieties and why? Curr Opin Cell Biol 17: 423-434. 
Philippidou P, Valdez G, Akmentin W, Bowers WJ, Federoff HJ, Halegoua S. 2011. Trk retrograde signaling requires persistent, Pincher-directed endosomes. Proc Natl Acad Sci 108: 852-857.

Pitulescu ME, Adams RH. 2010. Eph/ephrin moleculesA hub for signaling and endocytosis. Genes Dev 24: $2480-2492$.

Platta HW, Stenmark H. 2011. Endocytosis and signaling. Curr Opin Cell Biol 23: 393-403.

Polo S, Di Fiore PP. 2006. Endocytosis conducts the cell signaling orchestra. Cell 124: 897-900.

Puertollano R, Bonifacino JS. 2004. Interactions of GGA3 with the ubiquitin sorting machinery. Nat Cell Biol 6: 244-251.

Raiborg C, Stenmark H. 2009. The ESCRT machinery in endosomal sorting of ubiquitylated membrane proteins. Nature 458: 445-452.

Richardson DS, Rodrigues DM, Hyndman BD, Crupi MJ, Nicolescu AC, Mulligan LM. 2012. Alternative splicing results in RET isoforms with distinct trafficking properties. Mol Biol Cell 23: 3838-3850.

Roepstorff K, Grandal MV, Henriksen L, Knudsen SL, Lerdrup M, Grovdal L, Willumsen BM, van Deurs B. 2009. Differential effects of EGFR ligands on endocytic sorting of the receptor. Traffic 10: 1115-1127.

Sadowski L, Pilecka I, Miaczynska M. 2009. Signaling from endosomes: Location makes a difference. Exp Cell Res 315: 1601-1609.

Sadowski L, Jastrzebski K, Kalaidzidis Y, Heldin CH, Hellberg C, Miaczynska M. 2013. Dynamin inhibitors impair endocytosis and mitogenic signaling of PDGF. Traffic 14: $725-736$.

Salazar G, Gonzalez A. 2002. Novel mechanism for regulation of epidermal growth factor receptor endocytosis revealed by protein kinase A inhibition. Mol Biol Cell 13: 1677-1693.

Sancak Y, Bar-Peled L, Zoncu R, Markhard AL, Nada S, Sabatini DM. 2010. Ragulator-Rag complex targets mTORC1 to the lysosomal surface and is necessary for its activation by amino acids. Cell 141: 290-303.

Sandilands E, Akbarzadeh S, Vecchione A, McEwan DG, Frame MC, Heath JK. 2007. Src kinase modulates the activation, transport and signalling dynamics of fibroblast growth factor receptors. EMBO Rep 8: 1162-1169.

Sangwan V, Abella J, Lai A, Bertos N, Stuible M, Tremblay ML, Park M. 2011. Protein-tyrosine phosphatase 1B modulates early endosome fusion and trafficking of Met and epidermal growth factor receptors. J Biol Chem 286: $45000-45013$.

Schenck A, Goto-Silva L, Collinet C, Rhinn M, Giner A, Habermann B, Brand M, Zerial M. 2008. The endosomal protein Appl1 mediates Akt substrate specificity and cell survival in vertebrate development. Cell 133: 486-497.

Schiefermeier N, Teis D, Huber LA. 2011. Endosomal signaling and cell migration. Curr Opin Cell Biol 23: 615620 .

Schlessinger J, Shechter Y, Willingham MC, Pastan I. 1978. Direct visualization of binding, aggregation, and internalization of insulin and epidermal growth factor on living fibroblastic cells. Proc Natl Acad Sci 75: 2659-2663.
Schmees C, Villasenor R, Zheng W, Ma H, Zerial M, Heldin $\mathrm{CH}$, Hellberg C. 2012. Macropinocytosis of the PDGF $\beta$ receptor promotes fibroblast transformation by $\mathrm{H}$ RasG12V. Mol Biol Cell 23: 2571-2582.

Schmidt L, Duh FM, Chen F, Kishida T, Glenn G, Choyke P, Scherer SW, Zhuang Z, Lubensky I, Dean M, et al. 1997. Germline and somatic mutations in the tyrosine kinase domain of the MET proto-oncogene in papillary renal carcinomas. Nat Genet 16: 68-73.

Schmidt-Arras DE, Bohmer A, Markova B, Choudhary C, Serve H, Bohmer FD. 2005. Tyrosine phosphorylation regulates maturation of receptor tyrosine kinases. $\mathrm{Mol}$ Cell Biol 25: 3690-3703.

Scita G, Di Fiore PP. 2010. The endocytic matrix. Nature 463: 464-473.

Shattuck DL, Miller JK, Laederich M, Funes M, Petersen H, Carraway KL III, Sweeney C. 2007. LRIG1 is a novel negative regulator of the Met receptor and opposes Met and Her2 synergy. Mol Cell Biol 27: 1934-1946.

Sigismund S, Woelk T, Puri C, Maspero E, Tacchetti C, Transidico P, Di Fiore PP, Polo S. 2005. Clathrin-independent endocytosis of ubiquitinated cargos. Proc Natl Acad Sci 102: $2760-2765$.

Sigismund S, Argenzio E, Tosoni D, Cavallaro E, Polo S, Di Fiore PP. 2008. Clathrin-mediated internalization is essential for sustained EGFR signaling but dispensable for degradation. Dev Cell 15: 209-219.

Sigismund S, Confalonieri S, Ciliberto A, Polo S, Scita G, Di Fiore PP. 2012. Endocytosis and signaling: Cell logistics shape the eukaryotic cell plan. Physiol Rev 92: 273-366.

Simons M, Raposo G. 2009. Exosomes-Vesicular carriers for intercellular communication. Curr Opin Cell Biol 21: 575-581.

Singhirunnusorn P, Ueno Y, Matsuo M, Suzuki S, Saiki I, Sakurai H. 2007. Transient suppression of ligand-mediated activation of epidermal growth factor receptor by tumor necrosis factor- $\alpha$ through the TAK1-p38 signaling pathway. J Biol Chem 282: 12698-12706.

Skog J, Wurdinger T, van Rijn S, Meijer DH, Gainche L, Sena-Esteves M, Curry WT Jr, Carter BS, Krichevsky AM, Breakefield XO. 2008. Glioblastoma microvesicles transport RNA and proteins that promote tumour growth and provide diagnostic biomarkers. Nat Cell Biol 10: 1470-1476.

Sorkin A, von Zastrow M. 2009. Endocytosis and signalling: Intertwining molecular networks. Nat Rev Mol Cell Biol 10: 609-622.

Sousa LP, Lax I, Shen H, Ferguson SM, De Camilli P, Schlessinger J. 2012. Suppression of EGFR endocytosis by dynamin depletion reveals that EGFR signaling occurs primarily at the plasma membrane. Proc Natl Acad Sci 109: 4419-4424.

St Bernard R, Zheng L, Liu W, Winer D, Asa SL, Ezzat S. 2005. Fibroblast growth factor receptors as molecular targets in thyroid carcinoma. Endocrinology 146: 11451153.

Stern KA, Place TL, Lill NL. 2008. EGF and amphiregulin differentially regulate $\mathrm{Cbl}$ recruitment to endosomes and EGF receptor fate. Biochem J 410: 585-594. 
M. Miaczynska

Stuible M, Tremblay ML. 2010. In control at the ER: PTP1B and the down-regulation of RTKs by dephosphorylation and endocytosis. Trends Cell Biol 20: 672-679.

Suyama K, Shapiro I, Guttman M, Hazan RB. 2002. A signaling pathway leading to metastasis is controlled by $\mathrm{N}$ cadherin and the FGF receptor. Cancer Cell 2: 301-314.

Swaminathan G, Tsygankov AY. 2006. The Cbl family proteins: Ring leaders in regulation of cell signaling. J Cell Physiol 209: 21-43.

Taelman VF, Dobrowolski R, Plouhinec JL, Fuentealba LC, Vorwald PP, Gumper I, Sabatini DD, De Robertis EM. 2010. Wnt signaling requires sequestration of glycogen synthase kinase 3 inside multivesicular endosomes. Cell 143: $1136-1148$.

Tall GG, Barbieri MA, Stahl PD, Horazdovsky BF. 2001. Rasactivated endocytosis is mediated by the Rab5 guanine nucleotide exchange activity of RIN1. Dev Cell 1: 73-82.

Teis D, Wunderlich W, Huber LA. 2002. Localization of the MP1-MAPK scaffold complex to endosomes is mediated by 14 and required for signal transduction. Dev Cell 3: 803-814.

Teis D, Taub N, Kurzbauer R, Hilber D, de Araujo ME, Erlacher M, Offterdinger M, Villunger A, Geley S, Bohn $\mathrm{G}$, et al. 2006. p14-MP1-MEK1 signaling regulates endosomal traffic and cellular proliferation during tissue homeostasis. J Cell Biol 175: 861-868.

Treanor JJ, Goodman L, de Sauvage F, Stone DM, Poulsen KT, Beck CD, Gray C, Armanini MP, Pollock RA, Hefti F, et al. 1996. Characterization of a multicomponent receptor for GDNF. Nature 382: 80-83.

Valdez G, Philippidou P, Rosenbaum J, Akmentin W, Shao Y, Halegoua S. 2007. Trk-signaling endosomes are generated by Rac-dependent macroendocytosis. Proc Natl Acad Sci 104: $12270-12275$.

Varsano T, Dong MQ, Niesman I, Gacula H, Lou X, Ma T, Testa JR, Yates JR 3rd, Farquhar MG. 2006. GIPC is recruited by APPL to peripheral TrkA endosomes and regulates TrkA trafficking and signaling. Mol Cell Biol 26: 8942-8952.

Vergarajauregui S, San Miguel A, Puertollano R. 2006. Activation of 38 mitogen-activated protein kinase promotes epidermal growth factor receptor internalization. Traffic 7: 686-698.

Vieira AV, Lamaze C, Schmid SL. 1996. Control of EGF receptor signaling by clathrin-mediated endocytosis. Science 274: 2086-2089.

von Zastrow M, Sorkin A. 2007. Signaling on the endocytic pathway. Curr Opin Cell Biol 19: 436-445.

Wang Y, Roche O, Yan MS, Finak G, Evans AJ, Metcalf JL, Hast BE, Hanna SC, Wondergem B, Furge KA, et al. 2009.
Regulation of endocytosis via the oxygen-sensing pathway. Nat Med 15: 319-324.

Waterman H, Sabanai I, Geiger B, Yarden Y. 1998. Alternative intracellular routing of ErbB receptors may determine signaling potency. J Biol Chem 273: 13819-13827.

Waterman H, Katz M, Rubin C, Shtiegman K, Lavi S, Elson A, Jovin T, Yarden Y. 2002. A mutant EGF-receptor defective in ubiquitylation and endocytosis unveils a role for Grb2 in negative signaling. EMBO J 21: 303-313.

Wiley HS, Herbst JJ, Walsh BJ, Lauffenburger DA, Rosenfeld MG, Gill GN. 1991. The role of tyrosine kinase activity in endocytosis, compartmentation, and down-regulation of the epidermal growth factor receptor. J Biol Chem 266: 11083-11094.

Winckler B, Mellman I. 2010. Trafficking guidance receptors. Cold Spring Harb Perspect Biol 2: a001826.

Winograd-Katz SE, Levitzki A. 2006. Cisplatin induces $\mathrm{PKB} /$ Akt activation and $\mathrm{p} 38$ (MAPK) phosphorylation of the EGF receptor. Oncogene 25: 7381-7390.

Worthylake R, Opresko LK, Wiley HS. 1999. ErbB-2 amplification inhibits down-regulation and induces constitutive activation of both ErbB-2 and epidermal growth factor receptors. J Biol Chem 274: 8865-8874.

Wu C, Ramirez A, Cui B, Ding J, Delcroix JD, Valletta JS, Liu JJ, Yang Y, Chu S, Mobley WC. 2007. A functional dyneinmicrotubule network is required for NGF signaling through the Rap1/MAPK pathway. Traffic 8: 1503-1520.

Wu C, Cui B, He L, Chen L, Mobley WC. 2009. The coming of age of axonal neurotrophin signaling endosomes. $J$ Proteomics 72: 46-55.

Yamamoto H, Sakane H, Yamamoto H, Michiue T, Kikuchi A. 2008. Wnt3a and Dkk1 regulate distinct internalization pathways of LRP6 to tune the activation of $\beta$-catenin signaling. Dev Cell 15: 37-48.

Zhang B, Luo S, Wang Q, Suzuki T, Xiong WC, Mei L. 2008. LRP4 serves as a coreceptor of agrin. Neuron 60: 285297.

Zhu JX, Goldoni S, Bix G, Owens RT, McQuillan DJ, Reed CC, Iozzo RV. 2005. Decorin evokes protracted internalization and degradation of the epidermal growth factor receptor via caveolar endocytosis. J Biol Chem 280: $32468-32479$.

Zoncu R, Perera RM, Balkin DM, Pirruccello M, Toomre D, De Camilli P. 2009. A phosphoinositide switch controls the maturation and signaling properties of APPL endosomes. Cell 136: 1110-1121.

Zwang Y, Yarden Y. 2006. p38 MAP kinase mediates stressinduced internalization of EGFR: Implications for cancer chemotherapy. EMBO J 25: 4195-4206. 


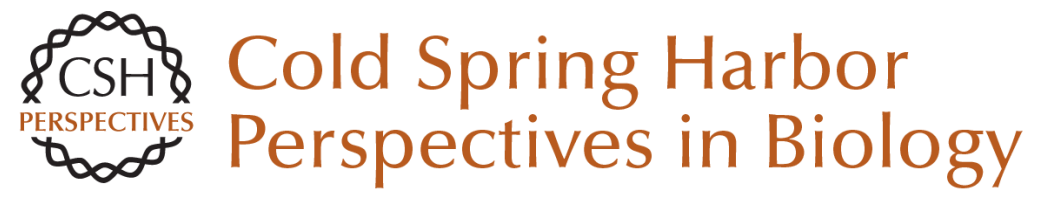

\section{Effects of Membrane Trafficking on Signaling by Receptor Tyrosine Kinases}

Marta Miaczynska

Cold Spring Harb Perspect Biol 2013; doi: 10.1101/cshperspect.a009035

Subject Collection Signaling by Receptor Tyrosine Kinases

CSF-1 Receptor Signaling in Myeloid Cells

E. Richard Stanley and Violeta Chitu

The EGFR Family: Not So Prototypical Receptor

Tyrosine Kinases

Mark A. Lemmon, Joseph Schlessinger and

Kathryn M. Ferguson

Tie2 and Eph Receptor Tyrosine Kinase Activation and Signaling

William A. Barton, Annamarie C. Dalton, Tom C.M.

Seegar, et al.

The Spatiotemporal Organization of ErbB

Receptors: Insights from Microscopy

Christopher C. Valley, Keith A. Lidke and Diane S. Lidke

Insulin Receptor Signaling in Normal and Insulin-Resistant States

Jérémie Boucher, André Kleinridders and C. Ronald Kahn

Central Role of RET in Thyroid Cancer

Massimo Santoro and Francesca Carlomagno

Receptor Tyrosine Kinase-Mediated Angiogenesis Michael Jeltsch, Veli-Matti Leppänen, Pipsa Saharinen, et al.
The Genesis of Tyrosine Phosphorylation Tony Hunter

Structure-Function Relationships of ErbB RTKs in the Plasma Membrane of Living Cells Donna J. Arndt-Jovin, Michelle G. Botelho and Thomas M. Jovin

Receptor Tyrosine Kinases: Legacy of the First Two Decades Joseph Schlessinger

The Role of Ryk and Ror Receptor Tyrosine Kinases in Wnt Signal Transduction Jennifer Green, Roel Nusse and Renée van Amerongen

Regulation of Receptor Tyrosine Kinase Ligand Processing Colin Adrain and Matthew Freeman

Molecular Mechanisms of SH2- and PTB-Domain-Containing Proteins in Receptor Tyrosine Kinase Signaling Melany J. Wagner, Melissa M. Stacey, Bernard A. Liu, et al.

Eph Receptor Signaling and Ephrins Erika M. Lisabeth, Giulia Falivelli and Elena B. Pasquale

For additional articles in this collection, see http://cshperspectives.cshlp.org/cgi/collection/

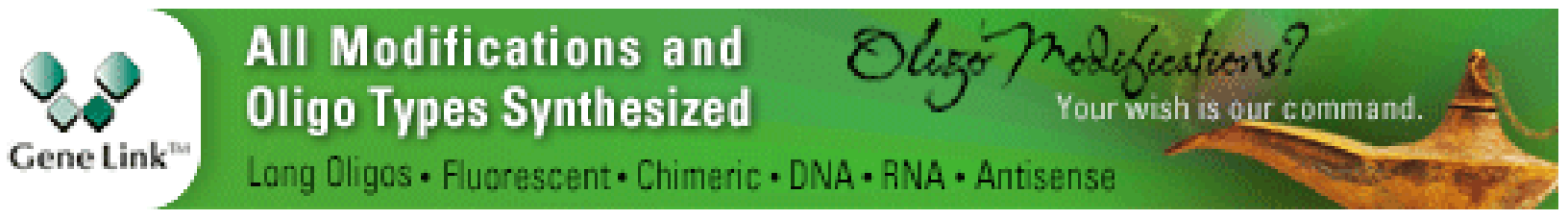




\section{Biology of the TAM Receptors \\ Greg Lemke}

Effects of Membrane Trafficking on Signaling by

Receptor Tyrosine Kinases

Marta Miaczynska

For additional articles in this collection, see http://cshperspectives.cshlp.org/cgi/collection/

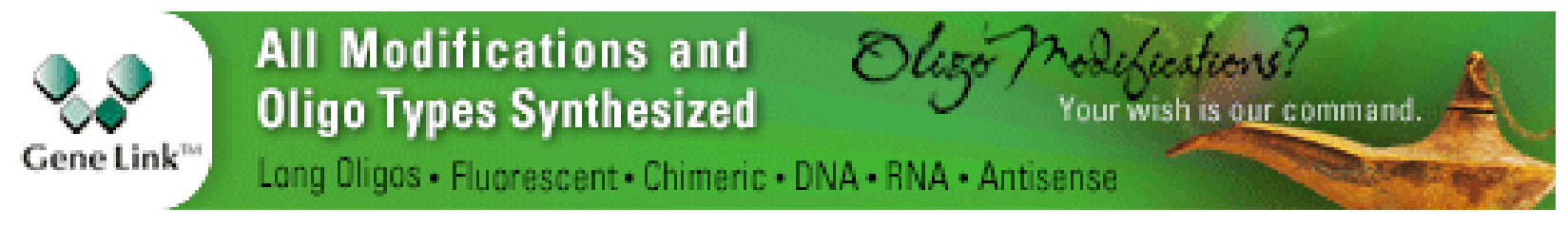

Copyright @ 2013 Cold Spring Harbor Laboratory Press; all rights reserved 